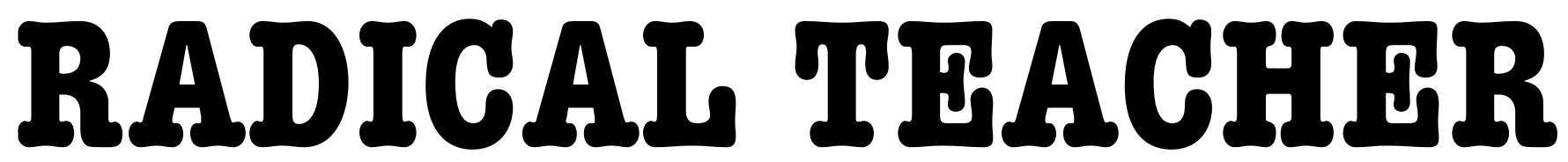

A SOCIALIST, FEMINIST, AND ANTI-RACIST JOURNAL ON THE THEORY AND PRACTICE OF TEACHING

\title{
Reading the Romance: Women, Patriarchy, and Popular Literature
}

(RADICAL TEACHER NO.37, 1990)

by Richard Ohmann

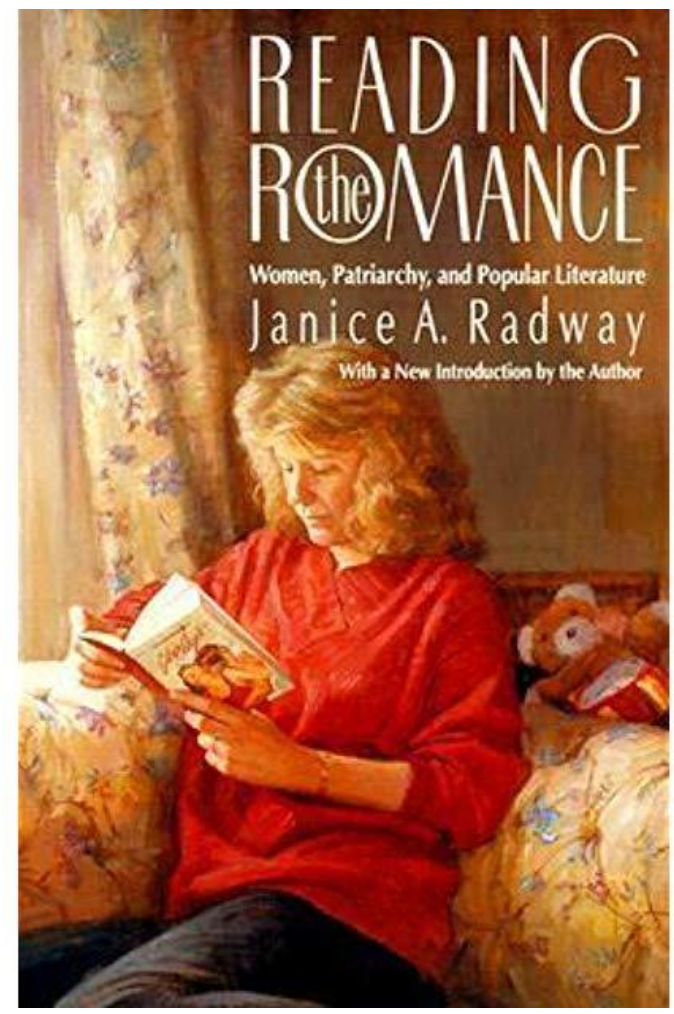

READING THE ROMANCE: WOMEN, PATRIARCHY, AND POPULAR LITERATURE, ED. JANICE A RADWAY (NORTH CAROLINA PRESS, 1984) 
Reading the Romance; Women, Patriarchy, and Popular Literature. Janice A. Radway. University of North Carolina Press.

$\mathrm{R}$ adway's book is about romances of the Harlequin and Silhouette variety, whose sales make them easily the most popular book genre in North America. She tells lucidly the story of their development in the context of the book industry, as this rather quaint, family business became fully a part of monopoly capital during the postwar period, and adopted the techniques of sales and audiencecreation long standard in other areas of mass culture.

But really, her book is about readers and reading. The phenomenal success of romances has naturally stirred the contempt of high culture critics, and more recently the concern of feminists, who have generally understood these narratives as promoting a kind of false consciousness, coating patriarchal values with a frosting of fantasy.

Radway avoids the condescension of this approach, noting that it presumes a stupefied mass audience unaware of what its experience means, until politically correct intellectuals intervene to explain the deeper significance of the texts.

Instead, Radway talked to actual readers -- a particular network of midwestern housewives, grouped around a woman who rated and sold romances through a newsletter and store. What she found was more complicated than the picture drawn by other feminist critics. The "Smithton women" appropriated romances as a pleasure strictly theirs, an antidote to the endless claims made on them by husbands and children, and a defense of "female" values like emotional sharing and (more or less) egalitarian marriage. Beyond that, the romances let readers identify with spunky heroines who "tamed" rough, sexy men and asserted their own rights. True, the women also, and finally, used romances to renew the energies they gave to conventional marriage and family. But for many, regular reading of these books fed a kind of proto-feminism that made for real gains in their lives, within the limits patriarchy sets for women. Some more recent romances even test those limits.

I used Reading the Romance in a class on popular fiction, made up entirely of college seniors, who were enthusiastic about the book and the subject. I believe that most college students would respond similarly: although Radway's book is quite sophisticated in method and theory, it is written in human prose, and it makes clear the real-world importance of its subject. Besides, that subject is one almost certain to have touched the lives of women in the class, whether or not they have ever been romance readers; and Radway's treatment poses a challenge to male readers more subtle than but as far-reaching as that offered by more direct feminist statements.
I had students read some romances and pool their responses, working partly in groups divided by sex. Are they the "right" readers for these books? Why and why not? What uses do they make of this reading? What happens to their high culture expectations, if any? We also worked with a group of magazine romances and confessions, two very distinct genres aimed at a more working-class audience, to see how Radway's analysis did and didn't work with these stories. A group of stories from Intimacy: Black Romance brought race into the picture. Some students have gone on to projects on men's fiction, in biker magazines and magazines like Penthouse. If I were doing a similar course again, I'd build such study into it, and maybe do a unit on Louis Lamour westerns and the like. With more time, I'd ask students to interview readers of genre fiction, as some of mine have chosen to do. Radway's study points out in many directions; I've only hinted at its richness. $((c))$ BY-NC-ND

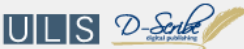

This work is licensed under a Creative Commons Attribution-Noncommercial-No Derivative Works 3.0 United States License. This journal is published by the University Library System of the University of Pittsburgh as part of its D-Scribe Digital Publishing Program, and is cosponsored by the University of Pittsburgh Press.

\section{RADICAL TEACHER}

No. 113 (Winter 2019) 